\title{
活性炭による溶存硫化水素の酸化と保持
}

$\begin{array}{ll}\text { 隅 倉 光 博*, } & \text { 田 㟝 雅 晴* } \\ \text { 岡 村 和 夫* } & \text { 和 田 信一郎 }\end{array}$

\section{Oxidation and Adsorption of Hydrogen Sulfide in Aqueous Solutions Using Activated Carbon}

\author{
Mitsuhiro SUMIKURA*, ", Masaharu TASAKI*, \\ Kazuo OKAMURA* and Shin-ichiro WADA** \\ * Institute of Technology, Shimizu Corporation, Etchujima 3-4-17, Koto-ku, Tokyo 135-8530, Japan \\ ** Faculty of Agriculture, Kyushu University, Hakozaki 6-10-1, Higashi-ku, Fukuoka 812-8581, Japan
}

\begin{abstract}
Changes in the forms of sulfur and oxygen consumed during the oxidation of hydrogen sulfide ions using activated carbon have yet to be elucidated fully. Therefore, in this study, an experiment on the oxidation of hydrogen sulfide ions in aqueous solution was carried out to investigate altered forms of the sulfur and oxygen consumed. The oxidation of hydrogen sulfide ions was promoted by activated carbon, and the oxidation of sulfur resulted in the formation of sulfate and thiosulfate ions. Additionally, X-ray photoelectron spectrometry indicated that elementary substances of sulfur adsorbed onto activated carbon. A material balance with an $84 \%$ abundance ratio of sulfur oxides and $82 \%$ oxygen consumption based on stoichiometry was calculated. The oxidized sulfur compound was confirmed to be safer than hydrogen sulfide ions.
\end{abstract}

Keywords: Hydrogen sulfide; Activated carbon; Catalytic agent; Oxygen oxidation

1. はじめに

有機物が蓄積し嫌気状態になった水域では, ヘドロの 蓄積や毒性と腐食性を有する硫化水素が発生し，環境污 染問題となっている。硫化水素の発生や貧酸素問題を改 善するためには，エアレーション等による環境改善対策 が行われているが, 酸素との接触効率が低いため改善効 率が悪く,より効果的に硫化水素を処理できる酸化剂や, 触媒が求められている。

一般的に活性炭は，その微細孔への吸着能力を利用し て溶存物質を分離，除去する目的で利用される。しか し，活性炭は物質を酸化還元する触媒機能も有し，酸素 雲囲気下では酸化触媒として，水素雲囲気下では還元触 媒として機能すると言われおり ${ }^{1,2)}$ ，硫化水素イオン等 の酸化剂としての利用が期待されている。溶存硫化物の 酸素酸化に関する研究では，活性炭を用いない酸素酸化 によって硫酸，亜硫酸，チ才硫酸，硫黄原子などに酸化 される ${ }^{3 \sim 7)}$ 報告や，その硫黄と酸素によるさまざまな酸 化反応機構を提案する報告 ${ }^{4 \sim 10)}$ に加えて, 活性炭によっ て溶存硫化物の酸化速度が促進することが報告されてい $ろ^{8 \sim 11)}$ 。

しかしながら，これまでの報告では，酸化反応によっ
て生成される各硫黄化合物の生成比率が不明であった り, 硫化水素イオンの減少量だけで活性炭の触媒効果を 評価 ${ }^{8 \sim 11)}$ しているため, 酸化還元反応前後の溶存形態や 物質量, 酸化に利用された酸素量についての検討はまだ 充分とはいえない。また，活性炭に吸着された硫黄成分 についは，二硫化炭素を使って活性炭から抽出される硫 黄化合物を定量した研究報告があるが10), 活性炭に吸着 された各硫黄化合物の形態やそれらの吸着量について明 らかにされていない。

有害物質を処理する際には，有害物質が減少すること が重要であるが, 減少した有害物質がどのように変化し たか，または何処へ移動したかを把握しておくことも重 要である。硫化水素イオンや貧酸素の問題を抱える水域 の改善を目的とした, 活性炭の触媒機能を利用した酸化 処理技術においても, 硫化水素イオンの減少速度だけで なく，最終的に硫黄形態が生物等に影響の少ない物質に 処理できているか, また酸化処理に必要な酸素量を把握 しておくことが重要である。

本報では，活性炭の触媒機能を用いた溶存硫化物の酸 化処理について, 酸化処理後に溶存する硫黄の形態や, 活性炭に保持 (吸着, 表面沈殿など複数の機構が予想さ れるのでここでは一般化して保持という用語を用いる)

* 清水建設株式会社技術研究所 $\overline{\mathrm{T}} 135-8530$ 東京都江東区越中島 3-4-17

** 九州大学大学院農学研究院 $=812-8581$ 福岡市東区箱崎 6-10-1

凤 連絡先 : m-sumikura@shimz.co.jp 
Table 1 Physical properties of activated carbon used.

\begin{tabular}{|lr|r|}
\hline packing density & $\mathrm{g} \cdot \mathrm{mL}^{-1}$ & 0.44 \\
\hline drying loss & $\%$ & 1.1 \\
\hline grain size (10 32 mesh) & $\%$ & 98.9 \\
\hline hardness & $\%$ & 98 \\
\hline residue on ignition & $\%$ & 5.9 \\
\hline $\mathrm{pH}$ & & 6.5 \\
\hline
\end{tabular}

された硫黄の形態を明らかにするとともに，酸化反応前 後の化合物の分析を行うことにより, 硫化水素イオンの 酸化処理に必要な酸素量についてまとめた。

\section{2. 実験方法}

\section{1 供試材料}

実験には，活性炭 GL-30S（株式会社ツルミコール社） を用いた。活性炭 GL-30S の諸物性を Table 1 に示す。 GL-30S は, 浄水打よび浄液用として脱色や排水処理に 用いられている石炭系の活性炭である。活性炭は超純水 で水洗し, $105^{\circ} \mathrm{C} て ゙ 20$ 時間乾燥後, デシケーター中で室 温まで领却したものを秤量し，実験に使用した。

硫化水素イオン水溶液は, 溶存酸素濃度を下げるため に窒素ガスで 1 時間以上曝気した超純水を用いた（溶存 酸素量を確認するために, 実験と同様な条件で超純水を 曝気する追加実験を実施した結果，溶存酸素濃度は 15 分後には $0.2 \mathrm{mg} \cdot \mathrm{L}^{-1}$ まで減少し, 1 時間後には $0.15 \mathrm{mg}$ $\cdot \mathrm{L}^{-1}$ まで減少していたため, 1 時間以上曝気した本実験 に用いた超純水の溶存酸素量は, $0.2 \mathrm{mg} \cdot \mathrm{L}^{-1}$ 程度まで減 少していたと推測される)。窒素ガスで曝気した超純水 に $\mathrm{Na}_{2} \mathrm{~S} \cdot 9 \mathrm{H}_{2} \mathrm{O}$ を硫黄換算で $100 \mathrm{mg}-\mathrm{S} \cdot \mathrm{L}^{-1}$ となるよう窒 素ガス雲囲気中で溶解し, $1 \mathrm{~mol} \cdot \mathrm{L}^{-1}$ 塩酸にて $\mathrm{pH}=8.0$ \pm 0.1 に調整した。

溶存硫化物は, $\mathrm{H}_{2} \mathrm{~S}$ (溶存硫化水素), $\mathrm{HS}^{-}$(硫化水素 イオン), $\mathrm{S}^{2-}$ (硫化物イオン) の形態をとり，以下の式 で示されるように2段階に解離する。

$$
\begin{array}{ll}
\mathrm{H}_{2} \mathrm{~S} \rightleftarrows \mathrm{H}^{+}+\mathrm{HS}^{-} & K_{1}=1.0 \times 10^{-7} \mathrm{~mol} \cdot \mathrm{L}^{-1} \cdots \cdots \cdots(1) \\
\mathrm{HS}^{-} \rightleftarrows \mathrm{H}^{+}+\mathrm{S}^{-} & K_{2}=1.0 \times 10^{-17.4} \mathrm{~mol} \cdot \mathrm{L}^{-1} \cdots \cdots(2)
\end{array}
$$

式の $K_{1}, K_{2}$ はそれぞれの解離定数 12,13$)$ を示しており, $\mathrm{pH}$ に対する各溶存硫化物の溶液中の存在比を解離定数 から計算した図を Fig. 1 に示した。中性から酸性側では, 溶存硫化水素の存在比が高くなり, 気化する可能性があ るので, 水溶液は $\mathrm{pH}=8.0 \pm 0.1$ に調整した。 $\mathrm{pH} 8.0$ の 時の溶存硫化物は, 解離定数による計算からその約 $91 \%$ が $\mathrm{HS}^{-}$（硫化水素イオン）の形態であると考えられる。

2.2 活性炭による硫化水素イオンの酸化実験

活性炭による硫化水素イオンの酸化反応を明らかにす るために, バイアル瓶を用いて硫化水素イオンの酸化 実験を行った。まず，バイアル瓶（内容積 $123 \mathrm{~mL}$ ）に, 秤量した活性炭を入れ $(0.05 \mathrm{~g}, 0.1 \mathrm{~g}), 100 \mathrm{mg}-\mathrm{S} \cdot \mathrm{L}^{-1}$ の 硫化水素イオン水溶液を $86 \mathrm{~mL}$ 入れた後, ブチルゴム 栓で密栓した。また活性炭を入れない実験系を比較対象 とした。この活性炭を入れた系と活性炭を入れない系の バイアル瓶は，予定した経過時間（0.5，1，2，3，4，5，

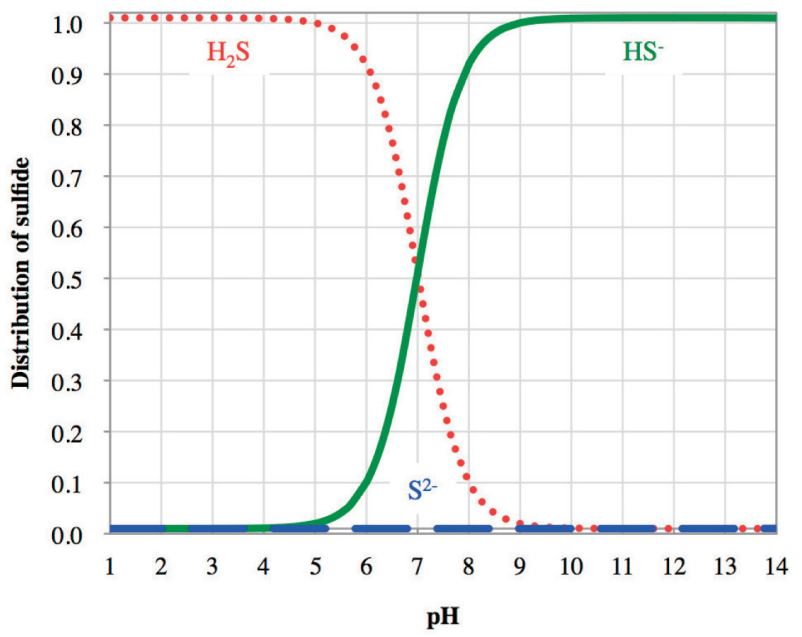

Fig. 1 Distribution of sulfide species as a function of $\mathrm{pH}$.

6.5，8，10，12 時間）ごとに 2 本ずつ開栓するため, そ れぞれ 20 本ずつ準備した。

これらのバイアル瓶を $20^{\circ} \mathrm{C}$ 恒温室で振とう機（NR80 ： TAITEC 社）で往復振とう（160 rpm）した。予定し た反応時間を経過したバイアル瓶は, 酸化反応による酸 素消費量を把握するために, 開栓前にバイアル瓶のヘッ ドスペースの酸素濃度をガスクロマトグラフ（GC323； GL Science 社）でそれぞれ測定した。分析には WG-100 カラム (GL Science 社, 材質; SUS, 内径; $1 / 4$ ", 長さ; 1.8 $\mathrm{m}$, キャリアガス; $\mathrm{Ar}$, 注入量; $0.3 \mathrm{~mL}$ ), $\mathrm{TCD}$ 検出器 ( $\mathrm{GL}$ Science 社）を用いた。その後バイアル瓶を開栓し, 硫 化水素イオン水溶液中の硫酸イオンをイオンクロマトグ ラフ (ICS-1500;DIONEX 社) で測定した。分析にはガー ドカラム IonPac AG12 A $(4 \times 50 \mathrm{~mm})$ と, 分離カラム IonPac AS12 A $(4 \times 200 \mathrm{~mm})$ (DIONEX 社, 溶離液; $2.7 \mathrm{mM}$ $\mathrm{Na}_{2} \mathrm{CO}_{3} / 0.3 \mathrm{mM} \mathrm{NaHCO}$, 流量 $; 1.5 \mathrm{~mL} \cdot \mathrm{min}^{-1}$, 注入量 ; $25 \mathrm{~mL}$ ）を使用した。残留硫化水素イオン濃度を液体検 知管（溶存硫化物 No. 211, 211LL, 211H; GASTEC 社） および，JIS K 010239.1 のメチレンブルー吸光光度法に 準じて紫外可視光分光光度計 (U-2000；HITACHI 社) で測定した。なお, 硫化水素イオン濃度の測定は, $\mathrm{HS}^{-}$ と $\mathrm{S}^{2-}$ の合計量を測定している。また溶液の $\mathrm{pH}$ と ORP は, それぞれ $\mathrm{pH}$ 電極 (pH METER D-52 ; HORIBA 社), ORP 電極（ORP METER RM-20P；TOA-DKK 社）で測 定した。

\section{3 硫黄成分の形態と酸化量の分析}

反応後の溶液中の硫黄成分や活性炭に保持された硫黄 成分の形態を明らかにするために, $1.28 \mathrm{~L}$ のブチル栓付 きメジウム瓶を用いて 2.2 と同様な実験を行った。活性 炭および硫化水素イオン水溶液は, それぞれ $1.00 \mathrm{~g}$, と $860 \mathrm{~mL}$ とした。また, 活性炭を用いた硫化水素イオン の酸化における空気（酸素）の影響について比較するた めに,メジウム瓶の気相を窒素で置換した系を設けた(空 気，および窒素の系をそれぞれ 2 本ずつ準備）。反応条 件は 2.2 と同様に $160 \mathrm{rpm}, 20^{\circ} \mathrm{C}$ とし, 反応時間は 12 時 間とした。

反応後, ヘッドスペースの酸素濃度を GC-TCD で測 定した。開栓後, 溶液中の硫黄成分の酸化形態（亜硫酸 イオン，チオ硫酸イオン）を分析するために，イオンク 
Table 2 Some experimental parameters for narrow scan in XPS.

\begin{tabular}{cccccc}
\hline & $\begin{array}{c}\text { sweep center } \\
(\mathrm{eV})\end{array}$ & $\begin{array}{c}\text { sweep width } \\
(\mathrm{eV})\end{array}$ & $\begin{array}{c}\text { Step } \\
(\mathrm{eV} / \text { point })\end{array}$ & $\begin{array}{c}\text { Dwell time } \\
(\mathrm{ms})\end{array}$ & $\begin{array}{c}\text { cumulated } \\
\text { number }\end{array}$ \\
\hline Wide & 693 & 1386 & 1 & 300 & 1 \\
O 1s & 532 & 20 & 0.1 & 298 & 4 \\
C 1s & 286 & 22 & 0.1 & 298 & 8 \\
S 2p & 400 & 16 & 0.1 & 298 & 32 \\
\hline
\end{tabular}

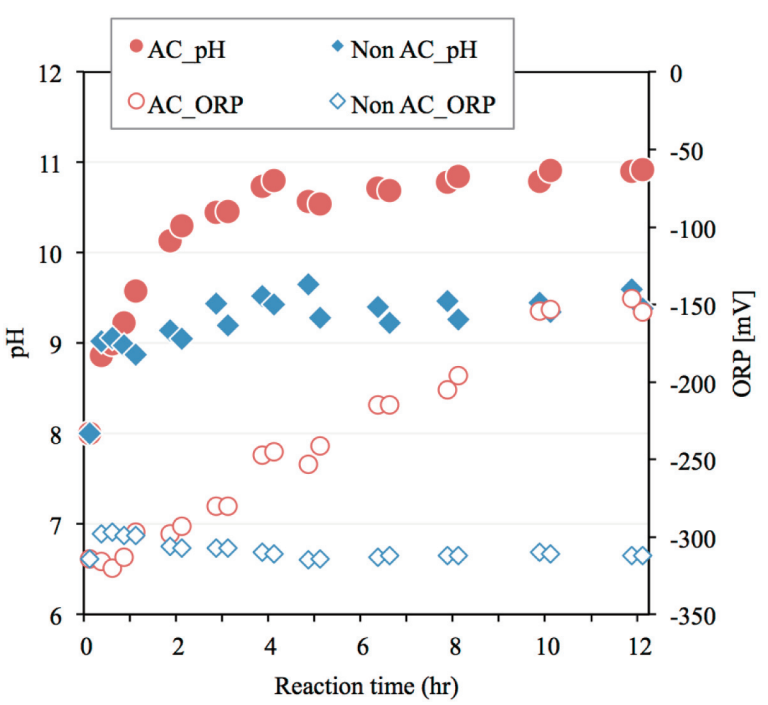

Fig. 2 Variation with time of $\mathrm{pH}$ and ORP.

ロマトグラフの測定時間を 2.2 の実験よりも長く設定し, 硫酸イオン, 覀硫酸イオン, チオ硫酸イオン濃度を測定 した。また，活性炭に吸着された硫黄の形態を明らかに するため, X 線光電子分光 (XPS) 分析装置 (AXIS-165; Shimadzu/Kratos 製）を用いて活性炭表面のX 線光電子 分光測定を行った。全試料において, 中和銃を使用し, 試料に含まれる元素の同定と各元素のピーク強度に関す る情報を得るために，ワイドスペクトル測定を行い，各 元素の主要ピークについてはナロースペクトル測定を 行った。ワイドスペクトルとナロースペクトルの標的 元素の測定条件を Table 2 にまとめた。活性炭に吸着さ れた硫黄成分の吸着量は，JIS K 2541-3（原油及び石油 製品 - 硫黄分試験法 第 3 部：燃焼管式空気方）に準じ て活性炭を燃焼管式空気法試験器にて燃焼し，燃焼ガス を $0.4 \% \mathrm{NaOH}$ の吸収液（0.3\% $\mathrm{H}_{2} \mathrm{O}_{2}$ 含有）に吸収させ, 吸収液中の硫酸イオンをイオンクロマトグラフで定量し 濃度を算出した。

\section{3. 結果および考察}

\section{1 活性炭による硫化水素イオンの酸素酸化実験}

空気 (酸素) による硫化水素イオンの酸化実験を行い, 活性炭 $(0.05 \mathrm{~g})$ がある系とない系の $\mathrm{pH}$ および酸化還 元電位（ORP）の経時変化を Fig. 2 に示した。硫化水素 イオン水溶液の $\mathrm{pH}$ は, 実験開始 30 分後に 9.0 付近まで 高くなり，その後，活性炭がある系（AC_pH）は時間 の経過とともに上昇し，12 時間後は 10.9 まで上昇した。 一方，活性炭がない系（Non AC_pH）の pH は 9.5 まで 上昇し安定していた。実験開始 30 分後には $\mathrm{pH}$ が 9.0 付

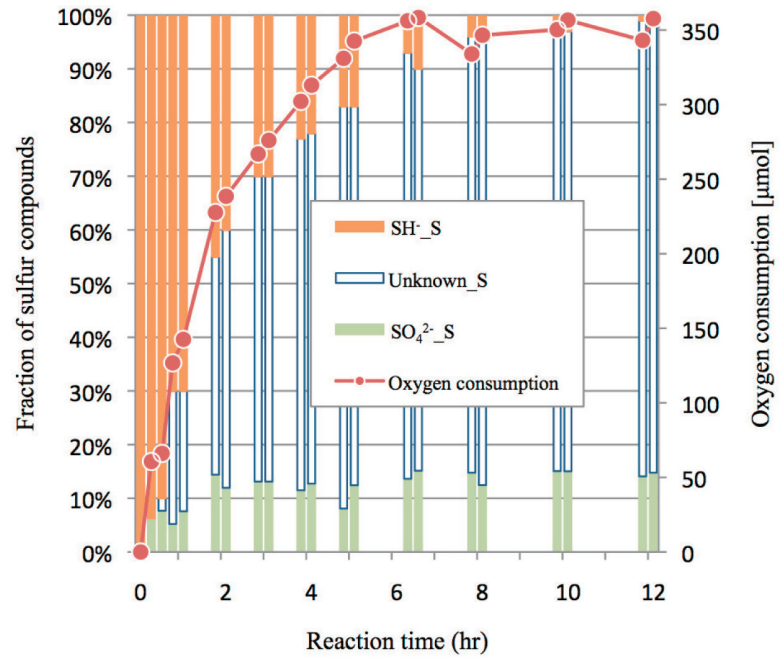

Fig. 3 Variation with time of fraction of sulfur compounds and oxygen consumption (with activated carbon: $0.05 \mathrm{~g}$ ) .

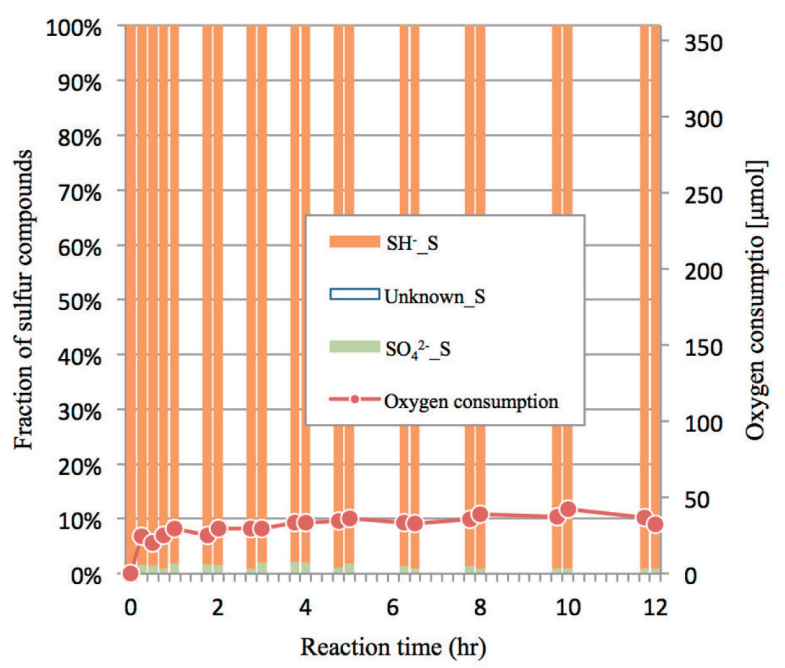

Fig. 4 Variation with time of fraction of sulfur compounds and oxygen consumption (without activated carbon).

近まで上昇しているので, 硫化水素イオン水溶液中の溶 存硫化物は, $99.9 \%$ が硫化水素イオン $\left(\mathrm{HS}^{-}\right)$の形態になっ ていると考えられる（Fig. 1)。また，酸化還元電位は， 活性炭がある系（AC_ORP）では時間の経過とともに上 昇しているのに対し，活性炭がない系（Non AC_ORP） ではほとんど変化しなかった。

活性炭がある系（活性炭量：0.05 g) とない系の各硫 黄成分と, ヘッドスペースの酸素消費量の経時変化をそ れぞれFig. 3, Fig. 4 に示した。各硫黄成分の $\mathrm{SH}^{-} \_\mathrm{S}$ は 水溶液中に残存する硫化水素イオン, $\mathrm{SO}_{4}{ }^{2-}{ }_{-} \mathrm{S}$ は溶液中 の硫酸イオン, Unknown_S は初期の硫化水素イオンか 
ら， $\mathrm{SH}_{-}^{-} \mathrm{S}$ と $\mathrm{SO}_{4}{ }^{2-}{ }_{-} \mathrm{S}$ を引いた硫黄分を表している。系 内に活性炭が存在すると (Fig. 3), 水溶液中の硫化水素 イオンは実験開始直後から減少し, 8 時間後には $4 \%$ ま で減少した。時間の経過と共に硫化物イオンが減少して いるにも関わらず， 2 時間経過以降の硫酸イオンは 10 〜 14\%で一定だった。このことから, 残り $80 \%$ の硫化 水素イオンは硫酸イオン以外の物質に変化していると推 測された。また, 酸素の消費量は, 硫化物イオンの減少 と比例して増加していた。

一方，活性炭がない場合（Fig. 4）は，反応時間 12 時 間後でも水溶液中の硫化物イオンはほとんどが残存し, 検出された硫酸イオンの硫黄は, 初期硫化水素イオン由 来の硫黄全体の 0 〜 $1 \%$ であった。また，ヘッドスペー スの酸素消費量は, 実験開始 15 分後に $10 \%$ 程度消費さ れて以降，ほとんど変化がなかった。

硫化水素イオンがほとんど減少していないにも関わら ず，酸素ガスが減少した理由として，ヘッドスペースの 酸素ガスが, 気液平衡により水溶液へ溶解したと考えら れる。そこで, バイアル瓶内の圧力を 1 気圧 $(101.325 \mathrm{kPa})$, ヘッドスペースの体積が $37 \mathrm{~mL}$, 空気の窒素ガスと酸素 ガスの比が 4: 1 として, ヘッドスペースの酸素ガスが 水溶液に溶解した体積を計算した。なお, 窒素ガス, 酸 素ガスの溶解度はそれぞれ 0.016 ，および $0.031 （ 20^{\circ} \mathrm{C} に$ おいて $101.325 \mathrm{kPa}$ の気体が水 $1 \mathrm{~cm}^{3}$ 中に溶解するとき の容積を， $0^{\circ} \mathrm{C}, 101.325 \mathrm{kPa}$ のときの容積に換算した值。 単位は, $\mathrm{cm}^{3}$ ) の值を用いた ${ }^{14)}$ 。酸素ガスを理想気体と みなし, 状態方程式から溶解した酸素ガスの物質量を求 めた結果, 酸素ガスの溶解量は $20.9 \mu \mathrm{mol}-\mathrm{O}_{2}$ となった。 酸素原子に換算すると, $41.8 \mu \mathrm{mol}-\mathrm{O}$ の酸素原子が水溶 液中に溶解することになる。活性炭を入れない実験系 で測定したバイアル瓶中の酸素消費量は, 実験開始後 4 〜 12 時間の平均值で $35.7 \mu \mathrm{mol}-\mathrm{O}$ であった。また, 計 算による酸素原子の消費量 $41.8 \mu \mathrm{mol}$ と実験による酸素 消費量 $35.7 \mu \mathrm{mol}$ の差 $6.1 \mu \mathrm{mol}$ は, バイアル瓶中の初期 酸素量 $623.8 \mu \mathrm{mol}-\mathrm{O}$ に対して, 約 $1 \%$ である。したがっ て, Fig. 4 の硫化水素イオンが減少していないにも関わ らず，実験開始後にヘッドスペースの酸素が消費されて

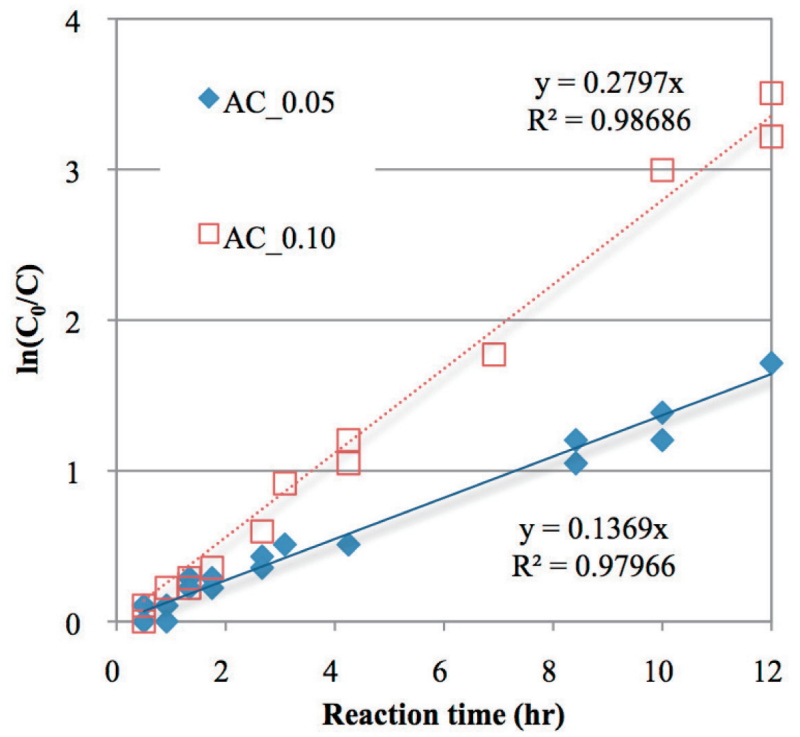

Fig. 5 Reaction velocity of hydrosulfide ion.
いたのは, 酸素ガスが硫化物イオン水溶液に溶解したた めだと考えられた。一方, 活性炭が存在する系 (Fig. 3) では酸素の減少が顕著だったことより, 硫化水素イオン の酸化に溶存酸素が消費され, 気相から液相への酸素の 溶解が進み, バイアル瓶の酸素消費が進んだと考えられ る。活性炭はこの溶解した酸素を利用して硫化水素を速 やかに酸化する働きがあると推測された。

初期濃度を $C_{0} \mathrm{mg} \cdot \mathrm{L}^{-1}, t$ 時間後の濃度を $C \mathrm{~mol} \cdot \mathrm{L}^{-1}$ と すると 1 次反応の速度式は, $-d C / d t=k t$ で表され, こ れを積分すると $\ln \left(C_{0} / C\right)=k t$ が得られる。この $\ln \left(C_{0} /\right.$ $C)$ を $t$ に対してプロットすると原点を通る直線になり, この時の傾きが速度定数となる。そこで, 硫化水素イ オンの減少量を $t$ 時間後に対する $\ln \left(C_{0} / C\right)$ を計算した 值をプロットした図をFig. 5 に示した。Fig. 5 の系列名 AC_0.05 は, 硫化物イオン水溶液 $86 \mathrm{~mL}$ に対して活性炭 を $0.05 \mathrm{~g}$ 加えた時, AC_0.10 は同様に活性炭を $0.10 \mathrm{~g}$ 加 えた時の反応速度を表している。AC_0.05, AC_0.10共 に原点を通る直線がえられたことから, 硫化水素イオン の反応速度は硫化水素イオンの濃度に対する一次反応で あることがわかる。また, 活性炭により硫化水素イオン の酸化が促進されている（Fig. 3, Fig. 4) ことや, 活性 炭量が 2 倍になると, 直線の傾きが示す反応速度定数も 約 2 倍になっていることから, 活性炭は硫化水素イオン の酸化触媒として機能していると推測された。また，流 通式で行った森ら ${ }^{9)}$ および川上ら ${ }^{11)}$ の実験では, 実験条 件等も異なるため反応速度は異なるが, 活性炭により硫 化物イオンの酸化速度が本研究と同様に促進することが 報告されている。

\section{2 酸化された硫黄成分の形態と量の結果}

$1.28 \mathrm{~L}$ のメジウム瓶で行った酸化実験後（12 時間後） の溶液中の硫黄成分濃度を Table 3 に示した。溶液中の 残存硫化水素イオン, 硫酸イオン, 亜硫酸イオン, チオ 硫酸イオンの濃度は, それぞれ $1.3,38.1$, 未検出（検 出限界 $\left.0.2 \mathrm{mg} \cdot \mathrm{L}^{-1}\right), 60.0 \mathrm{mg} \cdot \mathrm{L}^{-1}$ であった。

活性炭表面を $X$ 線光電子分光でワイドスペクトル測 定した結果をFig. 6 に示した。Fig. 6 は, 上から酸化実 験に用いた後 (Oxygen), メジゥム瓶の気相を窒素ガス で置換した実験に用いた後 (Nitrogen), および酸化実 験前（Blank）の活性炭をそれぞれワイドスペクトル測 定した結果を示している。Blank, Nitrogenの活性炭表 面には, 左から $530 \mathrm{eV}$ 付近に酸素の 1s 電子 (O_1s), $285 \mathrm{eV}$ 付近に炭素の $1 \mathrm{~s}$ 電子 (C_1s), $165 \mathrm{eV}$ と $103 \mathrm{eV}$ 付近にケイ素の $2 \mathrm{~s}$ 電子 $\left(\mathrm{Si} \_2 \mathrm{~s}\right)$ と $2 \mathrm{p}$ 電子 $\left(\mathrm{Si} \_2 \mathrm{p}\right)$ の 結合エネルギーを示すピークがそれぞれ確認できた。さ らに Oxygen ではこれらのピーク以外に, $228 \mathrm{eV}$ と 164 $\mathrm{eV}$ 付近に硫黄の $2 \mathrm{~s}$ 電子 $\left(\mathrm{S} \_2 \mathrm{~s}\right)$ と $2 \mathrm{p}$ 電子（S_2p）の

Table 3 Concentration of dissolved sulfur component after oxidation treatment.

\begin{tabular}{cc}
\hline ion species & $\begin{array}{c}\text { concentration } \\
\left(\mathrm{mg}-\mathrm{S} \cdot \mathrm{L}^{-1}\right)\end{array}$ \\
\hline $\mathrm{S}^{2-}$ & 1.3 \\
$\mathrm{SO}_{4}{ }^{2-}$ & 13.0 \\
$\mathrm{SO}_{3}{ }^{2-}$ & $\mathrm{ND}$ \\
$\mathrm{S}_{2} \mathrm{O}_{3}{ }^{2-}$ & 34.3 \\
\hline
\end{tabular}


結合エネルギーを示すピークが確認された。また，それ 以外の元素は顕著なピークは確認できなかった。これら のワイドスペクトルの結果から, 活性炭表面に硫黄成分 が保持されていると判断した。

Blank, Oxygen, NitrogenのC_1s の結合エネルギー付 近と S_2p の結合エネルギー付近をナロースペクトル測 定し，C_1s のピークを $284.8 \mathrm{eV}$ に補正した時の S_2p 付 近のピークをFig. 7 に示した。また, 硫黄化合物中の硫 黄の $2 \mathrm{p}$ 電子の軌道の結合エネルギー ${ }^{15)}$ を Table 4 に示 した。Table 4 に示した元素状硫黄の S_2p 電子の結合工 ネルギー值 $(164.2 \mathrm{eV})$ 付近に, Blank の活性炭では検 出されなかったピークが, Oxygenの活性炭で検出され た。また, Nitrogenの活性炭では, Oxygen と同じ位置 にブロードなピークが検出された。さらに, Table 4 に 示した各硫黄酸化物（硫酸ナトリウム, 亜硫酸ナトリウ ム, チオ硫酸ナトリウム）の S_2p 電子の結合エネルギー 值の位置 $(168.6,166.6,168.6 \mathrm{eV})$ 付近には, ピーク は観察されなかった。以上のナロースペクトル測定結果 から, 活性炭表面に保持されている硫黄成分の形態は, 元素状硫黄であると判断した。Ajay K Dalai らによる活

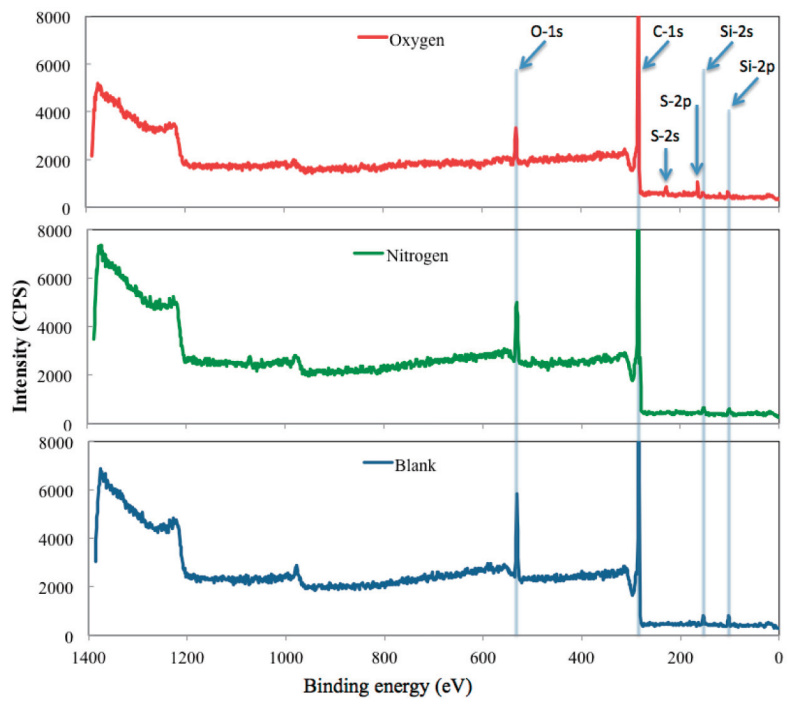

Fig. 6 Analyses of activated carbon by XPS (wide scan).

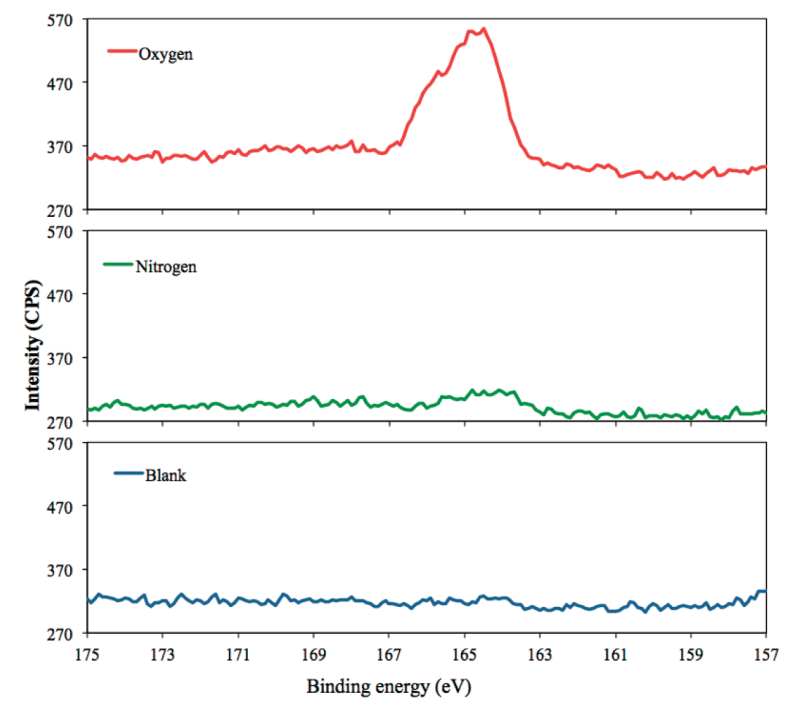

Fig. 7 Analyses of activated carbon by XPS (narrow scan_S2p).
性炭を含む硫化水素イオン溶液に連続的に酸素を供給す る実験でも, 二硫化炭素により活性炭から元素状硫黄が

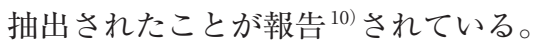

Oxygen, Nitrogen, Blank, の活性炭に含まれる硫黄成分 について, 活性炭に対する硫黄の重量比を Table 5 に示 した。空気および窒素ガス雲囲気下の実験後, それぞれ の活性炭に保持されている硫黄成分が, 質重量百分率で $3.41 \%, 0.74 \%$ 増加していたことから, 酸素が存在する 条件においてより多くの硫黄成分が活性炭に保持されて いることが明らかになった。これは活性炭の触媒機能に より硫化水素イオンが疎水性の単体硫黄に酸化されたこ とで, 活性炭に保持されやすくなったと考えられる。ま た, 窒素ガス雾囲気下でも硫黄成分が検出されたのは, 活性炭の微細孔に含まれていた酸素によって硫化水素が 酸化され，生成した硫黄が活性炭に保持されたと考えら れる。

活性炭を用いた本実験では, 溶液中や活性炭で検出 された硫黄化合物から, M. Avraham ら ${ }^{4}$ が報告した酸 化反応式と同様な反応が起こっていると推測された。 M.Avraham らは, 活性炭がない条件で, 低濃度の硫化水 素イオンが酸素によって酸化される反応式を硫黄の酸化 数の変化から, 以下の式(3)〜(6)を報告している。

$$
\begin{aligned}
& 2 \mathrm{HS}^{-}+3 \mathrm{O}_{2} \rightarrow 2 \mathrm{SO}_{3}{ }^{2-}+2 \mathrm{H}^{+} \\
& 2 \mathrm{SO}_{3}{ }^{2-}+\mathrm{O}_{2} \rightarrow 2 \mathrm{SO}_{4}{ }^{2-} \\
& 2 \mathrm{SO}_{3}{ }^{2-}+2 \mathrm{HS}^{-}+\mathrm{O}_{2} \rightarrow 2 \mathrm{~S}_{2} \mathrm{O}_{3}{ }^{2-}+2 \mathrm{HO}^{-} \\
& 2 \mathrm{~S}_{2} \mathrm{O}_{3}{ }^{2-}+\mathrm{O}_{2} \rightarrow 2 \mathrm{SO}_{4}{ }^{2-}+2 \mathrm{~S}
\end{aligned}
$$

式(3)で生成される亜硫酸イオンは, 還元剤として知られ ているように, 酸化条件化では速やかに式(4)や(5)の反応 が進み, 硫酸イオンやチオ硫酸イオンに酸化されるため, 本実験では検出されなかったと考えられる。また, 式(5) で生成されるチオ硫酸イオンは, 酸性条件下では不安定 で二酸化硫黄や硫化水素に分解されやすいが, 本実験の ようにアルカリ性条件下では比較的安定しており, 強い 酸化条件では式(6)のように徐々に硫酸イオンにまで酸化 されたと考えられる ${ }^{17)}$ 。

Table 4 Binding energy of $2 p$ orbital sulfur compound.

\begin{tabular}{llc}
\hline & Sulphur & $2 \mathrm{p}(\mathrm{eV})$ \\
\hline $\mathrm{S}(\mathrm{s})$ & & 164.25 \\
$\mathrm{Na}_{2} \mathrm{SO}_{4}$ & & 168.6 \\
$\mathrm{Na}_{2} \mathrm{SO}_{4}$ & & $168.9(2 \mathrm{p} 3 / 2)$ \\
$\mathrm{Na}_{2} \mathrm{SO}_{3}$ & & 166.6 \\
$\mathrm{Na}_{2} \mathrm{~S}_{2} \mathrm{O}_{3}$ & (central S) & 168.6 \\
& (peripheral S) & 162.5 \\
\hline
\end{tabular}

Table 5 Adsorbed sulfur contents by activated carbon.

\begin{tabular}{lccc}
\hline & oxygen & nitrogen & blank \\
\hline sulpher content (wt\%) & 3.69 & 1.02 & 0.28 \\
\hline
\end{tabular}




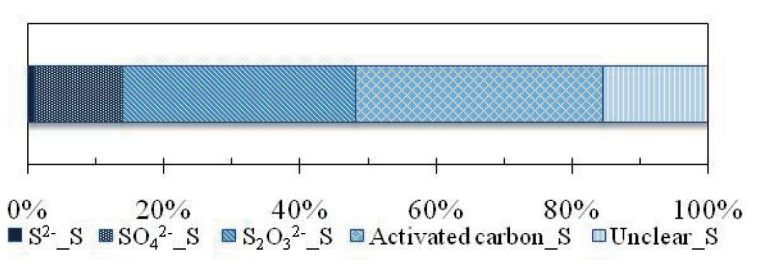

Fig. 8 Ratio of sulfur form after the activated carbon oxidation.

反応系に添加した硫化水素イオン（全量）に対する, 酸化実験後の溶液中及び活性炭に保持された各硫黄形態 の割合を，各形態の硫黄原子で換算した結果を Fig. 8 に 示した。この結果から反応後の各硫黄成分の生成比率は, 硫酸イオンとチオ硫酸イオンがそれぞれ $13 \%$ と $34 \%$ 溶 存し, 元素状硫黄 $\left(\mathrm{S}^{0}\right)$ として $36 \%$ が活性炭に保持さ れており，全体の約 $80 \%$ について明らかにすることが できた。

酸化によって生成された各硫黄化合物（硫化水素イ オン, 硫酸イオン, チオ硫酸イオン, 亜硫酸イオン) の生物毒性を比較するために, US EPA の ECOTOX Database $^{16)}$ でそれぞれのナトリウム塩についてDaphnia magnaの 24 時間暴露後の半数致死濃度を調べたところ, 硫化ナトリウムは $0.6 \sim 13.0 \mathrm{mg} \cdot \mathrm{L}^{-1}\left(0.01 \sim 0.17 \mathrm{mmol}^{-}\right.$ $\left.\mathrm{S} \cdot \mathrm{L}^{-1}\right)$, 硫酸ナトリムは $1116 \sim 8600 \mathrm{mg} \cdot \mathrm{L}^{-1}(7.86 \sim$ $\left.60.56 \mathrm{mmol}-\mathrm{S} \cdot \mathrm{L}^{-1}\right)$, チオ硫酸ナトリウムは $1334 \mathrm{mg} \cdot \mathrm{L}^{-1}$ $\left(16.87 \mathrm{mmol}-\mathrm{S} \cdot \mathrm{L}^{-1}\right)$, 亜硫酸水素ナトリウムは 72.4 $148.9 \mathrm{mg} \cdot \mathrm{L}^{-1}\left(0.8 \sim 1.44 \mathrm{mmol}-\mathrm{S} \cdot \mathrm{L}^{-1}\right)$ であった（亜硫 酸ナトリウムは半数致死量のデータがなく, 24 時間暴 露後の致死の間值で $\left.440 \mathrm{mg} \cdot \mathrm{L}^{-1}\left(3.49 \mathrm{mmol}-\mathrm{S} \cdot \mathrm{L}^{-1}\right)\right)$ 。 したがって, 活性炭を用いた酸化処理は, 生物（Daphnia magna）毒性の高い硫化水素イオンと比較て, 毒性が約 $200 ４ 00$ 倍低い硫酸イオンやチオ硫酸イオンに处理す る効果があると考えられる。

酸化実験によって消費された酸素に対する, 硫黄形態 別の酸素量, および水溶液に溶解した酸素量の割合を酸 素原子で換算した結果を Fig. 9 に示した。なお，硫化水 素イオンの酸化反応に利用された酸素量は, 酸化後の各 硫黄形態の量から計算し, 水溶液に溶解した酸素量は, 3.3 の活性炭が無い条件で酸素濃度が減少した時と同様 な計算から求めた。Fig.9 の結果から, 消費された酸素 は，硫酸に $27 \%$ ，千才硫酸に $27 \%$ ，硫黄分子に $19 \%$ 利 用され，溶存された酸素は $9 \%$ あるることが示唆された。 硫化水素イオンの途中の酸化機構は不明だが，本実験条 件での酸化反応は，検出できた各硫黄成分とその酸化反 応前後の化学量論から, 式(7) (9)の反応が起こっている と考えられる。

$$
\begin{aligned}
& 2 \mathrm{HS}^{-}+\mathrm{O}_{2} \rightarrow 2 \mathrm{~S}^{0}+2 \mathrm{OH}^{-} \quad \cdots \cdots \cdots \cdots \cdots \cdots \cdots \cdots \cdots \cdots \cdots(7) \\
& 2 \mathrm{HS}^{-}+2 \mathrm{O}_{2} \rightarrow \mathrm{S}_{2} \mathrm{O}_{3}^{2-}+\mathrm{H}_{2} \mathrm{O} \\
& \mathrm{HS}^{-}+2 \mathrm{O}_{2} \rightarrow \mathrm{SO}_{4}^{2-}+\mathrm{H}^{+}
\end{aligned}
$$

また，本実験で酸化実験後の形態を明らかにできなかっ た残りの 2 割の硫黄や酸素成分についてはさらに検討が 必要である。

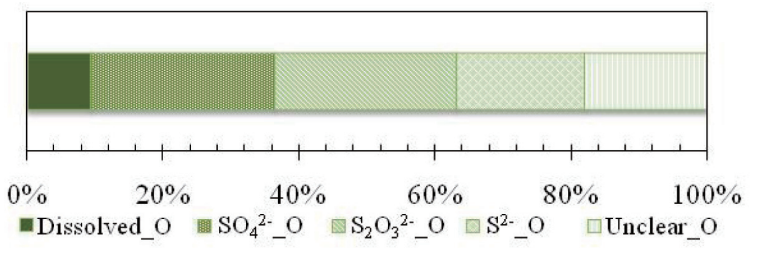

Fig. 9 Ratio of oxygen form consumed.

\section{4. まとめ}

活性炭を用いた硫化水素イオンの酸素酸化実験を密閉 瓶による試験を行い, 酸化実験後の硫黄形態と酸素量に ついて各種分析した結果，以下のことを明らかにした。

1) 活性炭と酸素によって酸化された硫黄成分の一部 は, 活性炭に保持され, その保持された硫黄成分の形態 は元素状硫黄であった。

2) 本実験条件で酸化された各硫黄成分を硫黄原子に 換算すると, 硫酸, チオ硫酸, 硫黄への酸化割合は, $13 \% ， 34.3 \% ， 36.3 \%$ であり, 硫黄成分の反応前後の形 態について，84\%の化学量論を明らかにした。また，酸 化された硫黄化合物は, 硫化水素イオンよりもより生物 毒性の低い物質であることを確認した。

3)活性炭による硫化水素イオンの酸素酸化に利用され た酸素について実験結果から計算すると, 硫酸イオン に27\%, チオ硫酸イオンに $27 \%$, 単体硫黄への酸化に $19 \%$, 水溶液に溶解した分が $9 \%$ で, 全酸素消費量のう ち $82 \%$ の酸素についてその物質収支が推定できた。

\section{謝 辞}

本研究における活性炭中の硫黄分析には, 九州大学中 央分析センターの X 線光電子分光 (XPS) 分析装置を 利用した。また，XPS 分析ならびに分析結果について， 井上弦学術研究員に多くの助言を頂きました。

（原稿受付 2012 年 11 月 16 日）

（原稿受理 2013 年 5 月 20 日）

\section{参 考 文 献}

1 ）藤川光男（1983）活性炭による酸化及び還元一硝酸イオン, 亜 硫酸イオンの酸化, 及び第二鉄イオンの還元-, 水処理技術, 24 (4), 321-324.

2 ）斎藤勇（1989）活性炭等による金属イオンの酸化, 還元および 吸着に関する研究, 公害資源研究所報告, 45, 1-68.

3 ) Janice D. Martin and L. D. Levanas (1962) New Column Removes Sulfide with Air, Hydrocarbon Processing \& Petroleum REFINER, 41 (5) , 149-153.

4 ) M. Avrahami and R. M. Golding (1968) The Oxdation of Sulphide Ion at Very Low Concentrations in Aqueous Solutions, Journal of the Chemical Society/Section A, 3, 647-651.

5 ) Joel D. Cline and Francis A. Richards (1969) Oxygenation of Hydrogen Sulfide in Seawater at Constant Salinity, Temperature, and $\mathrm{pH}$, ENVIRONMENTAL SCIENCE \& TECHNOLOGY, 3, 838-843.

6 ) Dennis J. O'Brien and Francis B. Birkner (1977) Kinetics of Oxygenation of Reduced Sulfur Species in Aqueous Solution, ENVIRONMENTAL SCIENCE \& TECHNOLOGY, 11, 1114-1120.

7 ) Kenneth Y. Chen and J. Carrell, Morris (1972) Kinetics of Oxidation of Aqueous Sulfide by $\mathrm{O}_{2}$, ENVIRONMENTAL SCIENCE \& TECHNOLOGY, 6 (6) , 529-537.

8 ) Jan B. Lefers, Wicher T. Koetsier and Willibrordus P. M. Van Swaaij (1978) The Oxdation of Sulphide in Aqueous Solutions, The Chemical Engineering Journal, 15, 111-120.

9 ) 森利克, 武内瀞士, 松田臣平 (1989) 撥水性触媒存在下におけ 
る硫化物イオンの酸素酸化, 日本化学会誌, 2, 204-208.

10) Ajay K. Dalai, A. Majumdar and Eric L. Tolefson (1999) Low Temperature Catalytic Oxidation of Hydrogen Sulfide in Sour Produced Wastewater Using Activated Carbon Catalysts, ENVIRONMENTAL SCIENCE \& TECHNOLOGY, 33, 2241-2246.

11）川上幸衛, 小森俊哉, 楠浩一郎 (1986) 活性炭触媒の疎水化に よる硫化ナトリウム水溶液の酸化反応速度の促進, 化学工学論文 集, 12 (3), 357-359.

12）鳥居泰男, 康智三 (1982) 定量分析化学改訂版, 486pp., 培風館, 東京.

13) Art A. Migdisov, A. E. Williams-Jones, L. Z. Lakshtanov and Yu V. Alekhin (2002) Estimates of the second dissociation constant of
$\mathrm{H} 2 \mathrm{~S}$ from the surface sulfidation of crystalline sulfur, Geochemica et Cosmochimica Acta, 66 (10) , 1713-1725.

14）国立天文台（2009）理科年表平成 22 年第 83 冊, 153 （503）pp., 丸善, 東京.

15) JEOL (1991) Handbook of X-ray Photoelectron Spectroscopy.

16) US EPA, ECOTOX Database, http://cfpub.epa.gov/ecotox/（2013年 5 月時点).

17) Peter Atkins, Jonathan Rourke, Mark Weller, Fraser Armstrong and Tina Overton (2008) シュライバー・アトキンス無機化学〈上〉第 4 版, 田中勝久, 平尾一之, 北川進 訳, pp.602-603, 東京化学同人, 東京.

\section{[論 文 要 旨 $]$}

活性炭を用いた溶存硫化物の酸化処理促進技術は, 酸化処理後の硫黄形態やその存在比, および酸素消費 量について，まだ十分に明らかにされていない。そこで，溶存硫化物の酸化前後の形態と酸素消費量を明ら かにするために, バイアル瓶を用いたバッチ式の酸化処理実験を行った。その結果, 活性炭の触媒作用によっ て硫化水素イオンは, 硫酸イオン, チオ硫酸イオンに酸化されて溶存していることが確認できた。次に， $\mathrm{X}$ 線光電子分光分析装置を用いて，活性炭表面にある元素とその電子状態を分析した結果，活性炭に保持され た硫黄成分は，元素状硫黄であることが示唆された。また，酸化処理前後の硫黄と酸素の化学量論について 計算した結果，それぞれ $84 \%$ と $82 \%$ の物質収支を推定することが出来た。さらに，酸化後の硫黄成分の生 物毒性について調べた結果，硫化水素イオンは活性炭を用いた酸化により，毒性の低い酸化物になっている ことを確認した。

キーワード : 硫化水素, 活性炭, 触媒, 酸素酸化 